\title{
Sosialisasi Pembinaan Sepakbola Usia Muda Dan Peranan Orangtua Bagi Pemain Sepak Bola
}

\author{
Kuncoro Darumoyo, Arief Nur Wahyudi, Andy Widhiya Bayu Utomo \\ STKIP Modern Ngawi \\ work.kuncorodarumoyo@gmail.com
}

\begin{abstract}
ABSTRAK
Pembinaan sepakbola usia muda memang menjadi kunci keberhasilan dalam menghasilkan pemain-pemain sepak bola yang handal di masa yang akan datang. Proses pembinaan juga harus dilakukan secara serius, sesuai program pembinaan dan ilmu kepelatihan sepak bola yang benar dengan peran orang tua terhadap anak di dalam keluarga adalah sebagai motivator, fasilitator dan mediator. Dengan sosialisasi ini diharap meningkatkan wawasan pelatih dan wali murid tentang pembinaan usia muda serta peran orang tua dalam dunia olahraga dengan penerapan kurikulum sepak bola Indonesia. Sasaran kegiatan pengabdian masyarakat ini adalah pelatih dan wali murid Internal FC Ngawi di Desa Ketanggi dengan jumlah sasaran 3 pelatih dan 30 wali murid. Kegiatan ini dilaksanakan dengan metode ceramah dilanjutkan dengan tanya jawab terkait dengan materi seminar yang telah disampaikan. Hasil pelaksanaan kegiatan pengabdian masyarakat ini mencakup keberhasilan target jumlah peserta seminar, ketercapaian tujuan seminar, ketercapaian target materi yang telah direncanakan, dan kemampuan peserta seminar dalam penguasaan materi. Program pengabdian masyarakat ini dapat diselenggarakan dengan baik dan berjalan lancar sesuai dengan rencana kegiatan meskipun belum semua peserta seminar dapat menguasai dengan baik materi yang disampaikan. Kegiatan ini mendapat sambutan baik terbukti dari keaktifan peserta mengikuti pendampingan dengan tidak meninggalkan tempat sebelum waktu seminar berakhir.
\end{abstract}

Kata kunci : Pembinaan, Usia Muda, Sepak bola, Orang Tua

\begin{abstract}
Youth development in football is indeed the key to success in producing reliable soccer players in the future. The coaching process must also be taken seriously, according to the correct football coaching and coaching program with the role of parents towards children in the family, as a motivator, facilitator and mediator. This socialization is expected to increase the insight of the coaches and guardians of students about coaching young people and the role of parents in the world of sports by implementing the Indonesian soccer curriculum. The object of this public dedication activity is Internal FC Ngawi trainers and guardians of student in Ketanggi Village with a total of 3 trainers and 30 guardians of students. This activity implemented by the discourse method followed by questions and answers related to the seminar material that has been presentation. The results of the implementation this public dedication activity include the success of the target number of seminar participants, the achievement of the seminar goals, the achievement of the planned material targets, and the ability of seminar participants to understanding the material. This public dedication activity program can be carried out successfully according to the activity plan, although not all seminar participants have understanding the material presented. This activity received a good response, as evidenced by the active participation of the participants in the mentoring by not leaving before the seminar ended.
\end{abstract}

Keywords: Coaching, Youth, Football, Parents 


\section{PENDAHULUAN}

Sepak bola merupakan salah satu cabang olahraga yang populer dan banyak diminati oleh masyarakat di dunia, begitu juga di Indonesia. Dari tahun ke tahun peminat olahraga sepak bola semakin banyak, hal ini terbukti dengan jumlah penonton yang semakin meningkat mulai dari anak anak sampai orang dewasa baik laki-laki maupun perempuan pada setiap pertandingan internasional, nasional maupun regional.

Sepak bola masa kini telah berkembang pesat dengan diikuti banyaknya tim sepak bola yang berusaha meningkatkan mutu, prestasi, maupun pamornya. Sejalan dengan perkembangan ilmu pengetahuan, menjadikan sepak bola memiliki keterkaitan dengan bidang ilmu lain. Dalam upaya meningkatkan prestasi olahraga, berbagai pengetahuan yang terkait ditinjau, diteliti dan diterapkan untuk menunjang prestasi yang optimal.

Untuk meningkatkan prestasi sepak bola, banyak faktor yang harus diperhatikan seperti sarana prasarana, pelatih yang berkualitas, pemain berbakat dan kompetisi yang profesional serta harus didukung oleh ilmu dan teknologi yang memadai. Sucipto dkk., mengemukakan bahwa faktor yang penting dalam pencapaian prestasi sepak bola adalah fisik dan penguasaan keterampilan dasar yang dimiliki oleh pemain itu sendiri, sehingga pandai bermain sepak bola (Sucipto dkk, 2000:7).

Perkembangan sepak bola di Indonesia telah jauh tertinggal dibandingkan negaranegara Asia lainnya. Hal tersebut bisa dilihat dari hasil Asian Games. Minimnya pemahaman pembinaan sepak bola pada usia muda menyebabkan antiklimaks pencapaian prestasi, tentu hal tersebut harus segera disikapi dengan cara mensosialisasikan pembinaan usia muda yang tepat dan sesuai kurikulum.

Scheunemann dkk, mengemukakan bahwa untuk menguasai keterampilan dan teknik bermain sepak bola yang baik, memiliki fisik prima, serta mental yang bagus, seseorang tentulah harus mengikuti proses pembinaan yang berjenjang dan berkesinambungan sehingga tujuan yang jelas akan dicapai pada tiap jenjang mulai dari SSB, remaja, junior sampai pada prestasi yang tertinggi pada usia senior (Scheunemann dkk, 2012:15).

Peranan orang tua juga merupakan faktor penting dalam kesuksesan pemain muda. Pemain akan lebih sering bertemu orangtua dibandingkan dengan pelatih, tentu sinergi dan pembinaan orang tua yang tepat akan menunjang prestasi pemain-pemain sepak bola Indonesia pada masa depan. Hal ini sesuai dengan Jalaludin Rakhmat yang menyatakan bahwa peranan keluarga merupakan tempat bimbingan yang pertama dan yang utama dari orangtuanya dalam hal membentuk kepribadian anak (Rakhmat, Jalaludin 2013: 204).

Ahmadin dkk., menyatakan bahwa Peran orangtua terhadap anak di dalam keluarga adalah sebagai motivator, fasilitator dan mediator (Ahmadin dkk, 2012). Lebih lanjut Soekanto, mengemukakan bahwa bentuk peran dan dukungan orang tua dapat dibedakan menjadi 2, yaitu bentuk peran dan dukungan orangtua yang bersifat materill maupun nonmaterill (Soekanto, 2012:24). 
Dengan adanya sosialisasi yang akan dilakukan diharapkan akan memberi wawasan kepada pelatih maupun orang tua wali murid Internal FC Ngawi tentang penerapan pembinaan usia muda agar mampu bersinergi guna mempersiapkan calon atlet sepak bola yang berkualitas pada masa depan. Karena tanpa menerapkan keilmuan terbaru dan sinergi pelatih dan orang tua wali murid akan sulit untuk mewujudkan generasi muda yang berkualitas untuk cabang olahraga sepak bola di Indonesia.

\section{BAHAN DAN METODE}

Sasaran kegiatan pengabdian masyarakat ini adalah pelatih dan wali murid Internal FC di Desa Ketanggi, Kabupaten Ngawi. Kegiatan workshop ini dilaksanakan 1 hari selama 2 jam 30 menit dan dilaksanakan bertempat di ruang serbaguna kantor Desa Ketanggi dengan jumlah khalayak sasaran yaitu 3 pelatih dan 30 wali murid.

Metode yang digunakan dalam pengabdian ini berupa ceramah bervariasi dan metode tanya jawab.

\section{HASIL}

Kegiatan pengabdian masyarakat yang dilaksanakan dengan acara tatap muka dalam bentuk seminar ini berjalan dengan baik dan lancar. Kegiatan ini dilaksanakan dengan metode ceramah bervariasi kemudian dilanjutkan dengan tanya jawab terkait dengan materi seminar yang telah disampaikan. Kegiatan ini dilaksanakan dalam satu kali pertemuan, yakni pada hari Minggu, 10 Januari 2021 pukul 14.00-16.30 WIB. Peserta kegiatan berjumlah 30 wali murid dan 3 pelatih Internal FC Ngawi.

Pelaksanaan kegiatan pengabdian masyarakat ini dilakukan oleh 3 orang dalam satu tim pengabdi yaitu Kuncoro Darumoyo, S.Or., M.Pd, Arief Nur Wahyudi, M.Pd, dan Andy Widhiya Bayu Utomo, M.Or dengan pokok bahasan yang disampaikan mengenai: 1) Pembinaan sepak bola anak usia muda di Indonesia. 2) Fase-fase pembinaan usia muda. 3) Kompetisi usia muda yang ideal 4) Penerapan kurikulum sepak bola Indonesia. 5) Peranan orang tua dalam dunia olaharaga.

Kegiatan yang diawali dengan ceramah bervariasi ini kemudian dilanjutkan dengan sesi tanya jawab. Berbagai pertanyaan diajukan secara antusias oleh para peserta dalam sesi tanya jawab. Secara garis besar inti dari pertanyaan para peserta adalah 1) Seperti apakah pembinaan usia muda sepak bola? 2) Mengapa perlu melalui fase-fase pembinaan sepak bola Indonesia? 3) Berapa pertandingan yang harus dicapai dalam sebuah kompetisi? 4) Apa saja peranan orang tua untuk anak dalam dunia olahraga?

\section{PEMBAHASAN}

Hasil pelaksanaan kegiatan pengabdian masyarakat ini secara garis besar mencakup beberapa komponen, yakni 1) Keberhasilan target jumlah peserta seminar. 2) Ketercapaian tujuan seminar. 3) Ketercapaian target materi yang telah direncanakan. 4) Kemampuan peserta seminar dalam penguasaan materi

Target peserta seminar seperti yang direncanakan sebelumnya adalah \pm 33 peserta dari Internal FC Kabupaten Ngawi. Dalam 
pelaksanaannya, kegiatan ini dihadiri oleh 33 orang peserta. Dengan demikian dapat dikatakan bahwa target peserta tercapai $100 \%$. Angka tersebut menunjukkan bahwa kegiatan pengabdian masyarakat ini apabila dilihat dari jumlah peserta yang mengikuti dapat dikatakan berhasil/sukses.

Ketercapaian tujuan seminar secara umum telah tercapai. Wawasan serta pemahaman pelatih dan wali murid Internal FC mengalami peningkatan. Namun keterbatasan waktu yang disediakan mengakibatkan tidak semua materi tentang deteksi dini dapat disampaikan secara detail.

Ketercapaian target materi pada kegiatan pengabdian masyarakat ini cukup baik. Hal ini dikarena materi seminar telah dapat disampaikan secara keseluruhan.

Kemampuan peserta dapat dilihat dari penguasaan materi yang masih kurang maksimal karena waktu yang singkat dalam penyampaian materi dan kemampuan peserta yang bervariasi. Hal ini disebabkan karena materi yang pembinaan usia muda yang ada dala kurikulum sepakbola Indonesia yang tergolong baru sehingga masih terdengar asing dalam benak pelatih dan wali murid.

Secara keseluruhan kegiatan pengabdian masyarakat ini dapat dikatakan berhasil. Keberhasilan ini selain diukur dari keempat komponen di atas, juga dapat dilihat dari kepuasan peserta setelah mengikuti kegiatan. Manfaat yang diperoleh pelatih dan wali murid adalah dapat menambah pengetahuan dan pemahaman konkret tentang pembinaan usia muda dan peranan orang tua bagi masa depan anaknya sebagai pemain sepak bola.

\section{KESIMPULAN DAN SARAN}

Program pengabdian masyarakat ini dapat diselenggarakan dengan baik dan berjalan lancar sesuai dengan rencana kegiatan yang telah disusun meskipun belum semua peserta seminar dapat menguasai dengan baik materi yang disampaikan. Kegiatan ini mendapat sambutan sangat baik terbukti dari keaktifan peserta mengikuti pendampingan dengan tidak meninggalkan tempat sebelum waktu seminar berakhir.

$$
\text { Berdasarkan evaluasi yang telah }
$$
dilakukan dapat diajukan beberapa saran antara lain waktu pelaksanaan kegiatan pengabdian perlu ditambah agar tujuan kegiatan dapat tercapai sepenuhnya dan adanya kegiatan lanjutan yang berupa workshop atau training sejenis yang diselenggarakan secara periodik sehingga dapat meningkatkan pemahaman pelatih dan wali murid.

\section{UCAPAN TERIMA KASIH}

Ucapan terima kasih kemi berikan kepada:

1. Bapak Istamar, M.Pd selaku selaku Ketua Yayasan Pendidikan Modern.

2. Bapak Sarwoto, S.Pd., M.Pd selaku Ketua STKIP Modern Ngawi.

3. Ketua LPPM STKIP Modern Ngawi.

4. Dosen PENJASKESREK STKIP Modern Ngawi dan Bapak Imam selaku ketua Internal FC yang memberikan kontribusi dalam pelaksanaan pengabdian kepada masyarakat. 


\section{DAFTAR PUSTAKA}

Ahmadin, N.F, Mustari, \& Gunawan (2012).

"Influence role of parents, teacher, learning motivation, methods, facilities and infrastructures to the recognition of qur'an students of SDIT Nurul Fikri Makassar". Journal Of Management. Volume 1 No. 2

Rakhmat, Jalaludin. 2013. Psikologi Komunikasi. Bandung: PT. Remaja Rosda Karya

Scheunemann, dkk. 2012. Kurikulum dan Pedoman Dasar Sepak Bola Indonesia. Jakarta: PSSI.

Soekanto, Soerjono. 2012. Sosiologi Suatu Pengantar. Jakarta: Rajawali Pers.

Sucipto, dkk. 1999/2000. Sepak Bola. Departemen Pendidikan Nasional.

\section{LAMPIRAN}

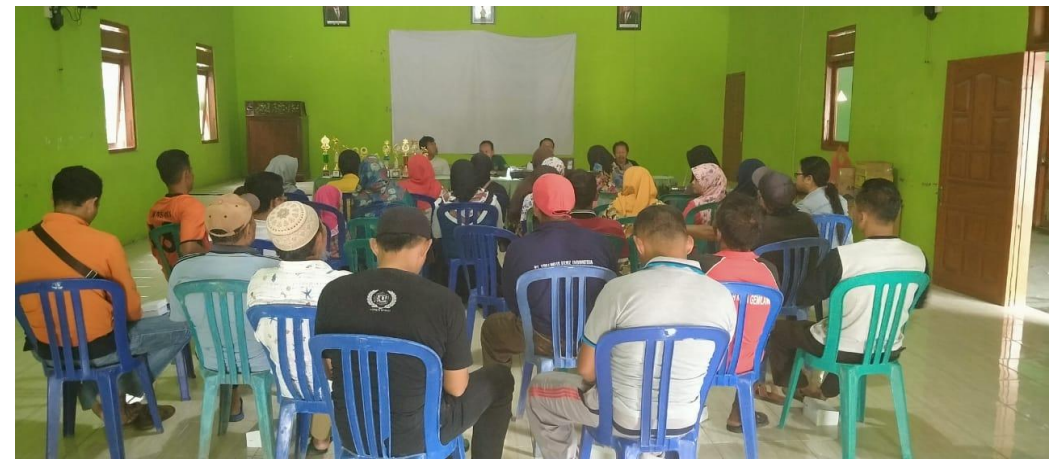

Gambar 1. Pemateri Menyampaikan Materi

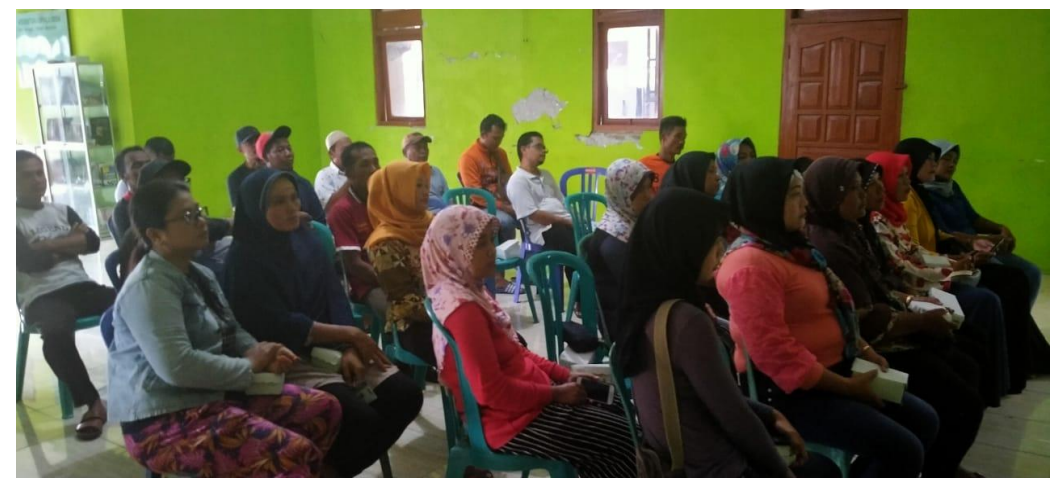

Gambar 2. Peserta Sosialisasi 